\title{
Good Bets, Bad Bets and Dark Horses: Allied Intelligence Officers' Encounters with German
}

\section{Civilians, 1944-45}

\section{Introduction}

During the Second World War, the Western Allies conducted intense research on morale and attitudes among Germans. This included surveys and interrogations of the captured Nazi elite and rank and file soldiers, and extended to clandestine recordings of conversations among German prisoners of war (POWs) in US-American and British captivity. The protocols and reports resulting from POW interrogations, surveys, and wiretapping informed and were part of Allied propaganda and psychological warfare. Allied interrogations involved not only German POWs, but also civilians, after the troops advanced through France and Belgium into Germany in the autumn of 1944. Intelligence officers sought to establish—along with any information that could provide tactical advantage—to what extent Germans were likely to offer resistance, who could be trusted, and, in order to expedite surrender or defeat, weaken morale and lower opposition through leaflet campaigns, broadcasts, and other psychological warfare operations. To this end, US-American and British intelligence officers interrogated German civilians whom they encountered along the way in the newly occupied towns and cities, often in evacuation and internment camps. Officers served in the Supreme Headquarters of the Allied Expeditionary Force's (SHAEF) Psychological Warfare Division (PWD), while others worked for military intelligence (G-2) or in the Counter Intelligence Corps (CIC). The resulting reports and profiles, which were often rich in detail and shared and circulated, fed into psychological warfare "output" and helped inform the wider outlook on Germans and Germany among the Allies. Yet in the research on Nazi violence and its aftermath, wartime interrogations of civilians, in particular, and Allied psychological warfare operations in general, rarely feature.

To a degree, this may have to do with the nature of the sources. None of the interrogations appear to have been recorded on tape. What remains are the reports compiled by intelligence officers, usually soon after interrogation, internal correspondence, personal papers, and post-war accounts, which include books and scholarly articles assessing and analyzing wartime psychological warfare work undertaken previously. Owing to the particularities of the Allied advance through Germany, there is a distinct bias towards interrogations in Western Germany, particularly the Rhineland, parts of what is now Baden- 
Wuerttemberg and, to a lesser degree, Bavaria. But these places were not necessarily only populated by local residents, but also evacuees and refugees from other parts of Germany. Leading Nazis had mostly fled elsewhere ahead of the arrival of the Allied troops. More importantly still, the reports are not verbatim transcripts but summaries, reflecting the interest and particular analytical and ideological lens of the interrogator and author or editor of a given report. Arguably, all of these sources tell us at least as much about the Western Allies in this particular period as they do about the Germans intelligence officers encountered.

In existing scholarship, material relating to psychological warfare is primarily used in studies of psychological warfare per se, which tend to focus on organizational structures and policies; Allied propaganda; and of interrogations with POWs as part of the research on "mentalities" and the Volksgemeinschaft. Here, the overrepresentation of male members of the Wehrmacht-both officers and rank and file soldiers-has left those outside the military and women, in particular, under-examined. ${ }^{1}$ Recent studies based on a separate and distinct corpus, the US Strategic Bombing Survey, whose Morale Division sought to establish the efficacy of Allied area bombing of industrial towns and cities for undermining civilian morale, have begun to buck this trend. ${ }^{2}$ In works on post-war information control and denazification, psychological warfare and other intelligence gathering feature only marginally, despite frequent continuities in personnel, who moved on to other, often successor, agencies and organizations (e.g. OMGUS, CIA), and thus continuities in technique, knowledge and understandings. ${ }^{3}$

This article is based on the reports, profiles, and internal correspondence resulting from interrogations of German civilians in the final months of the war, private letters and published post-war accounts (books and journal articles) by former intelligence officers about their experiences and work in this period. These are valuable sources for historical research into German responses to Nazism and the Allied occupation in this period and its aftermath, allowing us to examine the evolution of attitudes towards the Germans, the conclusions officers drew from their encounters, and some of the long-term ramifications of psychological warfare operations. Applying Sara Ahmed's conception of the "encounter," which usefully "suggests a meeting, but a meeting which involves surprise and conflict," 4 helps alert us towards the tensions involved in the interactions between intelligence officers and German civilians, and the limits of 
what can be known. ${ }^{5}$ As we shall see in this particular context, it also points us to the tension between intelligence officers' analyses, and the ways in which they were put to use.

Due to the limited scope of the article, the focus will primarily be on US intelligence officers, particularly but not exclusively those serving with PWD. I will address how they experienced their early encounters with German civilians, the ways in which the latter presented themselves, how the intelligence was used, and the ramifications of psychological warfare intelligence gathering and techniques. This article aims to reposition debates surrounding Allied notions of culpability, the extent of ordinary Germans' knowledge of atrocities and degree of denial by bringing the early occupation period from autumn 1944 onwards into view. I will show that intelligence officers' stance towards German civilians was fluid and at times ambiguous, with the encounter causing considerable distress to some of them. Their reports and correspondence further suggest that in this period, Germans readily professed to knowledge of atrocities. But contrary to intelligence officers' expectations, they failed to accept any guilt or responsibility, personal or collective. Finally, I will argue that the very foundations and techniques of Western Allied psychological warfare may have-inadvertently-reinforced and legitimised justification strategies that separated between "real" Nazis and everyone else. This was at odds with one of the central aims of Military Government, i.e. to inculcate a sense of culpability in Germans, and may have indeed undermined such efforts.

This article expands the focus beyond Wehrmacht soldiers and POWs, and intervenes into the on-going debate about "what Germans knew" and their degree of involvement in the "Third Reich." Prior to Germany's surrender and the full disclosure of National Socialist violence unleashed across Europe, the by now ubiquitous widespread denial of knowledge of atrocities by Germans had not yet formed in this period. ${ }^{6}$ The article further adds to scholarship concerned with the impact of Allied measures during the occupation on the ways in which Germans confronted the Nazi past after 1945, or failed to do so. Even before re-education, denazification, and legal prosecutions-whose origins and planning began long before the war ended-Allied psychological warfare operations may have had ramifications for the extent to which Germans were prepared to address guilt and responsibility. Specifically, we find a link between interrogations of both German POWs and civilians, psychological warfare leaflets and radio broadcasts, and their reception. 


\section{Encountering German Civilians: Allied Intelligence Officers in Germany, 1944-45}

The Western Allies' military intelligence gathering and psychological warfare operations during the Second World War were neither unified nor coordinated. The US-American Office of Strategic Services (OSS) and Office for War Information (OWI), the British Political Warfare Executive (PWE) and Ministry of Information (MOI), all ran their own psychological warfare operations, as did the military at different levels. ${ }^{7}$ Supreme Allied Commander General Dwight Eisenhower established the Psychological Warfare Branch (PWB) in October 1942 to co-ordinate US and British propaganda in the Mediterranean theatre of war. For propaganda in the European theatre of war following the Normandy landing, Brig. Gen. Robert McClure was put in charge of the newly created PWD, whose four key sections were plans and directives, intelligence, liaison, and operations. The Intelligence Section was constituted of field interrogators, an office in Paris (PWD-Forward) gathering the field interrogators' work and with responsibility for message production, and a research and analysis office in London (PWD-Rear). The Weekly Intelligence Summary was based on field interrogation reports, their analysis by PWD in London and Paris, and monthly POW surveys. The Intelligence Section of PWD collected psychological warfare intelligence, and reported on the attitudes of German soldiers, and later of German civilians, and the effectiveness of its propaganda. Their methods were quantitative surveys, qualitative (prolonged) interrogations, and document analysis. ${ }^{8}$ The overall goal of psychological warfare was to "erode the enemy's morale and will to resist."

Among the intelligence officers were many civilians, particularly in PWD, including academics, authors, or journalists, often with decidedly left-wing political leanings. Some were émigrés from Germany and Austria, many of them Jewish. ${ }^{10}$ Their perception of German civilians and POWs was influenced by different sources, including military handbooks, personal experiences and political outlooks, professional backgrounds (academic, military, media, and literature), the reports and summaries they received on a regular basis, their training, peers, milieus, and experiences in the field.

From October 1944 to May 1945, PWD's field intelligence officers interrogated hundreds of German civilians whom they came upon in evacuation and internment camps, and in the newly occupied towns and cities. Their mission was to "conduct surveys of public opinion and morale and to report on the relations of people" with Military Government (MG). ${ }^{11}$ Most prominently, Saul Padover and his 
colleagues Lewis F. Gittler and Paul Sweet, attached to $12^{\text {th }}$ Army Group, and later Ninth Army, created upwards of 30 special reports and more than 80 profiles of individuals. ${ }^{12}$ Beginning in the towns and cities of the Rhineland, they interrogated a wide variety of people from different socio-economic backgrounds and occupations, and diverse views towards Nazism. While none of them appeared to have been formally trained in interrogation and interview techniques, by the time Padover, Sweet and Gittler arrived in Germany in the autumn of 1944, they had already gained considerable experience and knowledge they then applied in the field.

All three had a connection to Germany, either professionally or personally, or indeed both. Padover and Sweet, who were friends, were both historians of German history, with both also serving at OSS Research \& Analysis branch in London prior to their PWD assignment. Both had studied at the University of Chicago. There, Padover was taught by Harold Lasswell, an influential figure in psychological warfare since the publication of Propaganda Technique in the World War in 1927 and Psychopathology and Politics in 1930, and who had taught several other OSS intelligence officers. ${ }^{13}$ Padover was born 1905 in Vienna to Jewish parents, and the family emigrated to the US in 1920. Sweet, who was born in 1907 in Pennsylvania, studied a semester each in Göttingen and Munich in 1929 and 1930, respectively, conducted research in Vienna in 1933-1934, and visited archives in Berlin in 1937. Padover continued his academic career after the war, while Sweet became a Foreign Service Officer. Both received a Bronze Star for their wartime service. Gittler, born in Chicago in 1914 into a family of orthodox rabbis and Silesian entrepreneurs, lived in Berlin for several years in the 1930s, together with his sister helping Jewish families smuggle out valuables and money, and seeking immigration visas for them. He returned to the US in 1937, and was eventually recruited by the OWI, working in Washington, D.C., Britain, and ultimately for PWD. He was a writer, who had published on Germany, including a book co-authored with Ladislas Farago, on German psychological warfare in 1941. After the war, he wrote the script for a film on the Jewish plight in Europe, Il Grido della Terra (The Earth Cries Out), directed by Duilio Coletti in 1949. He continued to write about Germany, including for Life magazine. ${ }^{14}$

In the same period, counter intelligence officers began to screen the civilian population for Nazi Party membership and war criminals, while military intelligence sought out information of tactical use for the military. These were not entirely isolated operations. For instance, PWD's intelligence officers would refer 
civilians they interrogated to CIC if they suspected them of war crimes or if they fell into the automatic arrest categories. PWD field interrogators operated relatively independently according to Sweet, which manifested in their many suggestively named reports and profiles. ${ }^{15}$ These included titles such as "Edelweiss Pirates: German Youth in Revolt?," "A Socialist who did Nazi occupation work in Russia," "A Nazi real estate broker," "A middle-aged Social Democrat, a little man who never compromised," "Unpolitical' German girl," "Father and Wife of an SS-Man," "Anti-Nazi daughter of a Nazi," and "A race-conscious and Nazified girl.”16

Interrogation reports varied in contents, length and tone. The profiles and reports compiled by Padover and Gittler, for example, focused either on one person, giving ample information about their backgrounds, views, and behaviors during interrogation, or on a group of people, but usually linking the reports to a more general analysis about e.g. German youth, Communists, or the political situation in a particular town. Subject of the profiles and reports were often very "ordinary" German civilians, whom Padover and his colleagues frequently questioned about their knowledge of atrocities, particularly against Jews and Soviet POWs. ${ }^{17}$

Intelligence officers' encounters with an amorphous group of German civilians raised difficult questions. What to make of (let alone do with) the largest group of Germans, i.e. those who were neither victims of Nazi persecution, nor "Nazis in the accepted sense of the word," as Daniel Lerner, Chief Editor of PWD and its Weekly Intelligence Summary, put it, yet who were nonetheless implicated in the Nazi state, was an important question for the Western Allies. Through interrogations, they sought to find out how the Germans "tick," the extent to which resistance and guerrilla warfare was to be expected, and whom they could trust during the occupation and after the end of hostilities. Their research, digested in the form of reports, further informed psychological warfare operations, such as leaflet and broadcast campaigns. ${ }^{18}$

In the Allied use of the term, the very category of "civilian" was highly fluid and wide-ranging. It encompassed essentially anyone who was not presently serving in the military On the German side, warfare in the East had severely and dangerously blurred the lines between civilian and combatant, not least in the violent pursuit of partisans, real or imagined, reprisals, and the killing of Jewish civilians under the guise of anti-guerrilla warfare. ${ }^{19}$ Spilling over into the Reich at the end of the war to the German home front, "total war" - fighting to the last at all costs, including the mobilization of children and elderly 
people-further put into question the extent to which anyone in Germany, who was not persecuted by the Nazis, could actually be a "civilian. Meanwhile, strategic bombing of German towns and cities by British and US forces in part aimed at demoralising the civilian population and accepted the loss of civilian lives, who were increasingly seen as combatants. ${ }^{20}$ As the fighting continued and the Allies advanced through Germany, civilians warranted special consideration. How they were perceived by the Allies shifted; this was not a fixed category or homogenous community of experience, neither at the time, nor in later representations.

Jewish intelligence officer Morris B. Parloff, a psychology graduate who had trained at Camp Ritchie in Maryland, landed in France in August 1944. As part of military intelligence, T-Force, 12 $2^{\text {th }}$ Army Group, he screened German civilians for membership in National Socialist organizations and war crimes. ${ }^{21}$ In a letter to his wife, he wrote about his encounters with civilians in Aachen: "I have spoken to PW's [prisoners of war] for a long time both in England and in France ... But I had never seen the cold, blank stares of hatred that I have seen in the eyes of some civilians in Germany." 22 Several months later, he told his wife about his own resentment towards the Germans: by April 1945, he confessed to having had enough of speaking to German civilians, and of his own reactions of hatred and disgust. While criticizing aspects of Allied occupation policy shortly after the end of the war, Parloff nonetheless agreed that, "We are not fighting an army alone. We are fighting a nation at war." ${ }^{23}$ In this context, intelligence reports warned not to trust civilians, as some Nazis would disguise themselves as civilians, Red Cross or foreign workers. ${ }^{24}$ Another report warned of "A Knife in Our Back" as German civilians had passed information about Allied movements and locations on to the German forces, and spread alarm as Allied troops advanced. The report further notes that

The civs [civilians] we are now encountering are as much a part of GERMANY 25 as the enemy troops we engage in battle. Realizing that they have no love for those ideals which we cherish, we may well expect to be treated scornfully whenever they may be in a position to choose their own line of action. When death and destruction became evident, German civs rapidly display their white flags of meekness. Remember that these flags are serving as a means of sparing German lives and property. It is true that they are lessening the cost of victory-they are also allowing 
German individuals who have no understanding of humane treatment to carry out activities which are nothing less than despicable collaboration.

All of these indications prove that any outward sign of friendliness by civilians toward our soldiers had no foundation in sincerity, but must have an ulterior motive. These people hate usthey are our enemies. We cannot afford to trust them in any way. We must deal with them firmly, justly, and only when necessary for furtherance of military objectives.

If we are cautious, the knife cleverly held in civ hands, and maliciously planned to be brutally thrust into our back may well turn into a lesson that the "Master Race" will never forget. GERMANY is conquered, and those who resort to force in an attempt to disprove this fact must be rendered ineffective. ${ }^{26}$ [all emphases in the original]

If the German leadership feared defeatism among the population and what it saw as a repetition of 1918, the Allies, too, feared to be "stabbed in the back." Faced with the spectre of Nazi guerrilla Werewolves ${ }^{27}$ and a Nazi last stand in the Alps, the so-called national redoubt, the Allies feared "civilians" much more than they did regular soldiers. Such warnings against trusting German civilians also served as reminders to uphold the Allied policy of non-fraternization. Ninth US Army provided a more sober analysis of the situation based on the interrogation of civilians. It reported in late April 1945 that the "bulk of the German people are 'War weary'; sickened by the damage to their homeland their attitudes range from a 'I'm glad it's all over', to a truculent admission of defeat and a stoic resolve to gird the loins and make the best of the situation." 28 There thus existed considerable differences in assessment of civilian responses, fluctuating over time, and depending on the reporting officers.

Besides capturing and reporting on the general mood and morale, part of intelligence research was also to differentiate among this very broad category of German civilians. Based on both quantitative surveys and reports resulting from qualitative interrogations from the field, Harry V. Dicks, psychiatrist with the Royal Army Medical Corps, and Edward A. Shils, a sociologist with the OSS and another disciple of Harold Lasswell's, established a typology. It separated between fanatical hard-core Nazis (Idealistic Zealots; Party Toughs; Concealed Fanatics); modified Nazis "with reservations" (Pseudo-Doubters; Idealists; Cynics); “unpolitical” Germans (Rural Population; Village Artisans; Minor Officials; Professional Soldiers); passive anti-Nazis (The Middle-Aged; The Very Young; The Opportunists); and active anti-Nazis (Political Anti- 
Nazis: Nationalist Conservatives, Centrists, Democrats; Religious Anti-Nazis: Roman Catholics, Evangelicals; Individualists). The typology, which reveals an acute awareness of the many layers of involvement in the Third Reich among German "civilians," was created so that PWD could identify the target audience that they regarded as most susceptible to psychological warfare output. ${ }^{29}$

Dicks was a World War One veteran, having served in military intelligence for the British Expeditionary Force in Russia. He was fluent in both Russian and German. As a qualified physician, he specialized on psychiatry, and published a monograph on psychopathology in 1939. He was adviser on German morale for military intelligence from 1942-44, and from 1944-45 with PWD, before assigned to the Intelligence Branch, Control Commission for Germany as advisor on German personnel and denazification in 194546. While it thus stands to reason that the typology created by Dicks and Shils would have had an impact on denazification, this ought to be explored in further studies. Dicks later published on authoritarian psychology and collective psychopathology, including a book on Licensed Mass Murder: A sociopyschological study of some SS killers (New York: Basic Books, 1973), based on interrogations. Dicks seems to have been unaware of the Frankfurt School's pre-war and war-time studies of authoritarianism. The above typology was created for this specific context, based on interrogations and other intelligence, influenced by Dicks and Shils's previous work, though we find echoes of Lasswell's scholarship. Shils became Assistant Secretary of the US home secretary and in 1943 joined PWD in London, before assigned to $12^{\text {th }}$ Army Group following the Normandy landing. He continued his academic career after the war at the University of Chicago, becoming an influential sociologist studying the role of intellectuals. While initially in favour of studies on the authoritarian personality, Shils later published a critique of the Frankfurt School's seminal work, arguing for what he saw as inherent similarities between left-wing and right-wing authoritarianism. ${ }^{30}$

The influence of this typology certainly continued shortly after VE Day, when guidance was issued by PWD for information control during the occupation, including on how to distinguish "Nazis" from "Germans," seen as important for the challenging tasks of eradicating National Socialism and reconstruction. ${ }^{31}$ It was more nuanced than the three lists - black, grey, white - for Nazis, followers, and anti-Nazis created during the war and used by CIC, ${ }^{32}$ or the five denazification categories established later in the US zone of occupation in 1946.33 In the new guidance, "Nazis" were distinguished into "three 
general types: the fanatic, the undercover man, the gangster." To identify them (and others) a catalogue of questions was designed to help personnel with the assignment of "how to recognise a Nazi." The questions were predominantly concerned with attitudes and opinions, e.g. regarding the "Jewish question," Nazi ideology, war criminals, resistance against the Germans, the causes of the war, and the Nazis' rise to power. A handful of questions concerned behaviors, primarily oppositional activities. But the guidance also points to "other types," which are divided into three groups. These "other types" are likely derived from Dicks and Shils's earlier typology described above.

As in the earlier work, we find a mix of demographic and socio-economic markers, attitudes, and behaviors: "Suspects, or 'Bad Bets'," "Non-politicals" or "Dark Horses", and finally "Useful Contacts and Potential Appointees, who may be described as 'Good Bets'." The Bad Bets included Opportunists and Cynics, and Reactionary Anti-Nazis; the Good Bets Political Anti-Nazis; Religious Anti-Nazis; Cultural Anti-Nazis; and Anti-Nazis on Personal Grounds. Notably, the Dark Horses group contained eight types of people the Allies could not quite make sense of, and regarded as potentially susceptible to psychological warfare: Country People; Minor Officials; Certain "Specialists" and Other Professionals; Small Town Artisans and Craftsmen; Professional Soldiers; Nazis by Force of Circumstance; The Very Young; and Disillusioned Idealists. ${ }^{34}$

As indicated above, these different "types" were based to a degree on intelligence work undertaken in Germany from autumn 1944 onwards. A discussion of the extent to which intelligence officers were aware of such typologies and other analyses and applied them in their field interrogations is beyond the scope of this article. Their reports and correspondence certainly point us to underlying notions of authoritarianism and obedience, and of a particular German national character. We also see the extent of suspicion with which intelligence officers viewed particular groups of German civilians.

While attitudes towards Germans fluctuated among intelligence staff, they appear to harden in early 1945 as the Allied troops advanced further into Germany and came upon the former concentration camps. The same has been said for US public opinion in this period, with an increasing number of respondents convinced of Germany's aggressive nature as details of atrocities and war crimes were made more and more public. ${ }^{35}$ In this context, the experiences of intelligence officers in their encounters with German civilians resulted in deep suspicion towards and in many cases blanket resentment of German civilians. 
Padover, one of PWD's most influential intelligence officers, grew increasingly exasperated after months of interrogating ordinary Germans; this got much worse after he visited the liberated camp of Buchenwald. ${ }^{36}$ In an internal report written around Christmas 1944, he had still condemned Allied "hard policy" against all Germans, and argued that not all Germans were Nazis, even calling on the Allies to make use of "experts" who joined the Party only out of careerism but not conviction. ${ }^{37}$ But several months later, after VE Day, he wrote to his wife that the Germans, having killed, enslaved and massacred millions of people, were no longer part of the family of nations and constituted a cursed and muchloathed people, and only the next generation would be able to make a new beginning. ${ }^{38}$ The book about his eight months of interrogating Germans, which he published as early as 1946 was written through this particular lens, seen through the later experiences and encounters, with the report from Christmas 1944 feeling strangely disjointed among the account's overall tone. Somewhat surprisingly, apart from withholding a handful of names of US American army and intelligence officers, Padover's book, although published so soon after the war, is surprisingly frank and appears to have evaded any Government controls, censorship and classification despite seemingly largely based on the reports and profiles he created in his capacity as PWD intelligence officer. ${ }^{39}$

Like many of his contemporaries, Padover believed in the notion of German collective guilt - not only for having allowed the Nazis to rise to power but also for not rising up against them - and saw it rooted in a particular national character which was prone to authoritarianism, obedience, and a lack of compassion, even towards their own compatriots. In his view, the bulk of Germans was to be held responsible. Seemingly fed up with Germans putting all the blame on Hitler, Padover wrote in his notebook in May or June 1945, "IT'S NOT JUST HITLER [sic]." before the Nazis rose to power, he must have been all too aware during his service in Germany that he, too, and his parents could have fallen victim to Nazi violence, had they not left Austria long before the Nazis rose to power-although this is not a topic he ever broaches in his reports nor his post-war account. Padover's left-leaning politics informed his attitudes towards his German interlocutors. He was most frustrated by Social Democrats and Communists, and by what he regarded as their failures and compromises, while reserving some of his praise for those whom he felt had remained steadfast. ${ }^{41}$ In his 
post-war account, he often highlighted atrocities against both Soviet POWs and Jews, just as he had done in his PWD reports.

The (on-going) effort to differentiate between different types of involvement in Nazism, of positioning within the Nazi state, and of wider complicity did not happen in isolation. Intelligence officers brought with them prior conceptions, shaped by official doctrine, their own experiences, and political leanings. But the impressions of the devastation caused by Nazi Germany's war, encounters with German civilians, former forced laborers and concentration camp inmates, and the harrowing images from the liberated camps also helped both forge and reinforce a certain notion of guilt and responsibility, and of German reactions.

"That all Germans ... must bear the mark of shame has simply not occurred to these people": Collective Guilt Doctrine between Expectations and Reality

Intelligence officers had ingested, to varying degrees, the "doctrine of collective guilt." 42 Upon landing in Europe, they encountered extensive war damage, victims of Nazi violence, and hatred of the Germans, and they very much expected their interlocutors to accept personal and/or collective guilt and responsibility. A key component and aim of Allied military government policy was that Germans should understand and acknowledge their responsibility for National Socialism and its downfall. ${ }^{43}$ Notably, the terms guilt and responsibility were not defined or distinguished, and often used seemingly interchangeably. The charge of "collective guilt" was never fully translated into policy, especially after the end of the war, and as there had been differing strands of thinking throughout. Subsequently, Germans used the collective guilt charge to their advantage to reject outright any kind of responsibility and to claim unfair treatment. ${ }^{44}$

Observations regarding the lack of a sense of guilt among the German civilians are commonplace in the reports and profiles submitted by intelligence officers. Among them was United States Marine Corps Reserve Captain John P. Dickson, who, based on his interrogations of civilians during a trip to the Western Rhineland area from 21-28 March 1945, reported for PWD:

None of the civilians interrogated, from the janitor's wife to the university professor, gave evidence of sensing personal guilt in the slightest degree. That all Germans, regardless of individual political leanings, must bear the mark of shame has simply not occurred to these 
people. Affirmations of hatred of their "Nazi" masters, expressions of relief at the arrival of the Allies-especially of the Americans-are too frequent and commonplace to merit attention. Some referred to their "Government" as "criminals", but others, like the janitor's wife, obstinately declined to employ any term stronger than "those idiots" ... who are insisting ... upon the senseless destruction of the "Fatherland". ...

No admission was made to a member of the occupying forces that it was a regime composed of anything worse than mentally unbalanced individuals. Again, a complete lack of a sense of guilt. ... If, as of course often occurs, Hitler, and now more often Himmler, is named as the chief criminal, the interrogator is left to feel that his subject is in no way related to these men or to their colleagues, that there is no inner connection, no link between the rulers and the ruled....

If care is not taken, these people may succeed in convincing some of us that in the final analysis, they, as Rhinelanders and Catholics, are nothing more than innocent bystanders at the scene of the crime....

The long-term problem, the eradication of the Nazi spirit and of German militarism, is closely associated with one of the major difficulties concerning our M.G. [Military Government] men how to identify a "genuine" Nazi. Screening can accomplish a great deal ... But in the natural desire to eliminate all suspected Nazi sympathisers, ownership of the Party button is being overestimated as a final criterion. On the other hand, little attention is paid to the degree of support an individual lent to the Party. ${ }^{45}$

The "degree of support" was to become an important aspect of denazification proceedings, and its measurement was built into the development of the denazification questionnaire, or Fragebogen. ${ }^{46}$ Yet there were disagreements among the Allies as to the extent to which only leading Nazis or other, more lowly but committed figures should be included in the programme, or what constituted merely "nominal" or "active" Nazi Party membership. ${ }^{47}$

Of particular note is the above use of the "bystander" term, the earliest thus far identified in this context. The term became highly influential, if contested, through Raul Hilberg's 1992 book Perpetrators, Victims, Bystanders. Dickson warns of Germans pulling wool over Allied eyes, of pretending to have been "innocent bystanders," thus evading re-education and facing their own personal or collective 
responsibility. From the outset, then, the term "bystander" was introduced and used, somewhat polemically, to describe and problematize not so much behaviors but self-representations, and to point towards the challenges facing re-education and occupation. Indeed, the use of the term implies its very opposite, that there can in fact be no innocent bystanders. Dickson's warning echoes into the present and testifies to a crucial period, in which a particular set of German responses to Nazism began to emerge and solidify. The fact that guilt and responsibility were ill-defined, not only in Dickson's writing, could suggest that the terms denote a particular, perhaps specifically US-American, shared notion of what one might call "civic" guilt or responsibility. Protestations of innocence qua impotence simply failed to register with intelligence officers, who were not only outraged at the atrocities and destruction wrought by Germans, but held different notions of civic duty, agency, and an individual's role and position vis-à-vis the state, as seen in Dickson's above nod to the link between the "ruler and the ruled." It was thus also an encounter of one set of values with another, which materialised in the frequent expressions of indignation, incomprehension, and exasperation.

Dickson was not alone in noting a lack of a sense of guilt among Germans. In the second half of March 1945, Padover and Gittler composed one of their many "profiles" of Germans they encountered, entitled "An ex-SS man." The five-page report, longer than the average one to three pages which they usually submitted, also gives a clue as to the way in which they conducted their interrogations.

Padover and Gittler describe how they had come across a 21-year-old man from Krefeld. Due to lung problems resulting from his third combat wound, H.K. had been released from the Waffen-SS in December 1944. Having spent much time in hospital in the summer of 1944, he began to fear death and to distance himself from Nazism. Padover and Gittler however found that his thinking was profusely saturated with Nazi ideology, no matter how hard he tried to conceal it. At the time of his release from the Waffen-SS, H.K. was SS-Standarten-Oberjunker in the 600th Paratrooper Battalion, which had fought partisans in Yugoslavia from late 1943. Prior to this, H.K. had served as a signaller in Russia and Ukraine in 1941 and 1942. Before joining the Waffen-SS sometime around spring 1941, he had been in the Hitler Youth, in a branch engaged in police and patrol duties, and in this capacity was present at, perhaps involved in, and still openly celebrated the destruction of the Krefeld synagogue in November 1938. His father worked as a chemist for IG Farben. Both left the Catholic Church in 1935. Later in this 
conversation, H.K. admits that in all of 1941, they made no prisoners, shooting them in the back of the neck after interrogation, adding that "terrorists and bandits" were dealt with in much the same way.

Would he shoot anyone on a direct order? He hesitated an instant, and then hunched his shoulders. "If it is an order, one must do it. Most of those we are ordered to shoot are criminals anyways. Otherwise, we would not have received an order to shoot them.

We asked if he had heard of Maidanek [sic] in Lublin. He said yes, he had been in Lublin in 1943, recovering from his second wound. Had he heard of the 850,000 gassed and cremated there. He corrected us quickly ....."That is an exaggeration. I only knew of 16,000 and they were all shot in the back of the neck. The SS TOTENKOPF unit did most of the work there. They had to do it on order. Yes, it was repulsive.....but it had to be done....It is true that we cremated the bodies...We didn't want another Katyn, you know," he said with a clever smile. He described Katyn as a massacre of Polish officers by Russians. "We did not make their mistake of burying the dead. We cremated them."

Asked how this affected him from the humanistic point of view, he said: We never thought much about it. Most of them were Jews or were in a concentration camp. Everyone in such a camp is probably a criminal. Otherwise, how would he have got into the camp in the first place? You must understand that it is not a personal thing. The man who receives an order to shoot a civilian cannot take time out to find out who is and who is not a criminal. We leave that to the higher authorities." ...

During this admission of shooting civilians and prisoners in Poland, Russia and Yugoslavia, we (Lt. Peter Hart was present) showed no sharp reaction, and [H.K.] himself demonstrated no uneasiness about his own participation in the shootings. His attitude was that it was all in the past, that he had merely obeyed "orders," and that the victims were "criminals" and thus deserved execution. His standpoint was that he is now a civilian and wanted to study in peace and his military past was honourable and forgotten. ...

PS: CIC is holding [H.K.], but they believe they may have to release him for lack of a definitive charge. ${ }^{48}$ [all emphases in the original] 
The former Waffen-SS member's whereabouts and fate after this encounter are uncertain. ${ }^{49}$ The fact that CIC may have released him "for lack of a definitive charge" alerts us to some of the problems concerning Allied notions of judicial culpability and the relative dearth of knowledge they possessed at this stage. The 16,000 dead in Majdanek he talks about most likely relate to the massacre of 18,000 Jews on 3 November 1943, as part of Operation Harvest Festival, when the surviving Jews in the Lublin district were murdered, and which was carried out by SS forces brought in from outside the camp. Majdanek had been the first major camp liberated by the Red Army already in July 1944. Reports regarding the number of deaths at Majdanek have varied and have long been overestimated. Tomasz Kranz has calculated the figure to be 78,000 of which 59,000 were Jews. ${ }^{50}$ Padover and his team had considerable leeway in the way in which they conducted interrogations, which did not have to follow any particular protocol, bar that of non-fraternisation. H.K.'s profile sees Padover and Gittler explain how they would show no reaction, perhaps so he would continue talking. The fact that they felt the need to spell this out also points us towards the enormity of what they encountered in this particular interrogation, which stood out as their only direct contact with a self-professed mass murderer.

Later PWD reports from June 1945 also complained about the "lack of any sense of war guilt among the ordinary German $\mathrm{P} / \mathrm{W}$ [prisoner of war] and his false expectations of conditions under American occupation," the problem thus not being limited to civilians alone. ${ }^{51}$ Young people, too, as shown in letters written shortly after the end of the war, "follow the example of their elders in declining to accept the doctrine of collective German responsibility for Nazism and the war." Some even tried "to turn the 'guilt' argument back against the western powers, condemning Allied governments for not having done more to resist Hitler before 1939." 52 Countering such refusal to accept guilt and responsibility was part of Allied re-education strategy. Captain Donald McGranahan, who belonged to the Intelligence Section, where he organized and controlled the "flow and use" of different types of intelligence, ${ }^{53}$ had visited the newly liberated Buchenwald concentration camp on April 19-20, 1945, where he encountered child survivors. In his report to the Chief of PWD's Intelligence Section, he explained that he had "promised to speak to the children over Radio Luxembourg," which was under SHAEF control from September 1944 until November 1945, and "to speak about them for the benefit of a wider audience. The children were quite eager to tell what they had gone through. A copy of the talk, which is appended, includes most 
of the points which were brought out. Several of the more gruesome details were omitted, such as the story of one child who saw his elders biting each others [sic] throat in starvation and madness." He further reported that the Polish-Jewish children wanted to go the USA, rather than return to Poland, and that they harbored "intense feelings of revenge against the Germans." ${ }^{4}$ The radio broadcast (whether or not it was actually broadcast could not yet be established), entitled "A Talk to the Children of Buchenwald," while addressing the children, was ultimately aimed at a wider German audience for the purpose of re-education:

... I am sorry that it is not possible for every German [sic] to go and talk with you boys of Buchenwald, as I did. You may recall that we did bring one German woman there to see you. Before she went to Buchenwald with us, she did not appear to feel any particular guilt or shame about what had taken place there. We took her before a group of you and asked the first boy where his mother was. "Gassed", was the answer. We asked the next boy where his father was. "Shot, kaput [sic]", was the answer. We asked how many of the boys in this group had lost their parents. Every one raised his hand. This German woman also heard several of you tell your personal histories. When she went away from Buchenwald she was unable to speak. When we finally left her, she told us she would devote the rest of her life trying to make up for the crimes done to you and other children like you.

I do not know whether this woman was sincere or not, and as you will probably say, her good intentions are a little late. But I can tell you that you do not need to worry about your future.-If there is anything that the Allied armies are fighting for, it is this: that the injustices and crimes and cruelties committed against children like you will be amended. ... ${ }^{55}$

McGranahan's radio address, and the correspondence with PWD's Intelligence Section, are remarkable for a number of reasons. The encounter had certainly left a considerable impression on him. Yet the proposed broadcast apparently omitted not only the most horrific details related to him but also the Jewishness of some of the children he had talked to. It further claimed that the Allies had been fighting to end injustices against children all along, thus accommodating a particular narrative of "why we fight" whose hold continues into the present and which distorts the more complex development of Western Allies' engagement in the war. McGranahan's pedagogic example of the German woman who was shown 
the liberated camp bought into and validated, perhaps inadvertently, German claims of ignorance about camp conditions, while also overestimating or misjudging the educational impact such direct confrontation would have on German civilians. The broadcast reads as offering a pathway to Germans that would allow them to acknowledge the crimes that had been committed in the camps, while insisting on their own prior ignorance and innocence.

If Germans were mostly perceived to deny guilt and responsibility, some reports insisted that they in fact did feel some subconscious sense of guilt or at least displayed signs of a bad conscience. Notably, such claims were made where reports addressed atrocities. Having traveled through occupied Germany in the first two weeks of April 1945, Lerner contended: "All this elaborate structure of psychological evasion is built upon a deep sense of guilt. Nearly every German has some knowledge of the atrocities committed within Germany and in foreign lands. A surprisingly large number admit to knowledge of the 'Gaswagen' and how it was used-although the name LUBLIN [sic] does not always strike a spark." ${ }^{56}$ Echoing Lerner's assertions is intelligence officer Morris Janowitz, who concluded from a survey of German civilians shortly after Germany's surrender that "The only gap in the protective wall which Germans have erected to keep out all feelings of guilt about atrocities seems to be in connection with the mistreatment of German Jews. Here was a fact that even the most simple-minded German could not hide from his own consciousness. The Germans remembered the destruction of Jewish shops and synagogues, the systematic discrimination and final rounding-up and deportation of the Jews from their own community. ... Some go so far as to lay the blame for the present difficulties of Germany on the mistreatment of the Jews." Especially the defeat at Stalingrad was assigned to Nazi policy towards the Jews; yet there was still no "realization of the need for developing individual responsibility in order to prevent the recurrence of the same misdeeds; it is more a wish or hope for absolution. Probing and discussion never produced any feelings of guilt. When a sense of shame was noted, it was a purely personal reaction without any feelings of coresponsibility." ${ }^{57}$

German post-war strategies of self-exculpation were built on two pillars: claims of a lack of knowledge of Nazi policy of mass murder and extermination, and a lack of influence on any such policy. ${ }^{58}$ These claims still resonate into the present. But as PWD reports indicate, this was not so in the final months of the war in intelligence officers' encounters with Germans, in which the latter spoke relatively freely about 
atrocities, though without always possessing the full details. But already at the time, most Germans recognised no link between their own actions and attitudes and the violence they recounted. Shortly after the war, PWD collated a report regarding the "German civilian mentality: Reaction to atrocities," i.e. reactions to a concentration camp brochure the Allies had produced, observing that:

Almost without exception, responsibility for misdeeds placed exclusively on Party or SS. German people "helpless \& cannot be taken to task." ...

Nazis, near-Nazis, nationalists look on such atrocities as inevitable consequences of war \& hatreds it stirs up. Acts were connected with wellbeing of Reich \& people as whole. People who refuse to pass any moral judgment on the war. DENIAL OF ANY GUILT IS OFTEN ATTEMPT TO DENY ONE'S OWN SHARE IN A GENERAL GUILT. Yet widespread bad conscience about systematic atrocities toward Jews. This probably because of conviction that world Jewry is in fact the very great power which Goebbels had said it was, \& is now wreaking retribution. Apologies for past actions toward Jews are method for winning absolution." ${ }^{59}$ [all emphases in the original]

The report further highlighted "Resistance" to their attempts to "inculcate some sense of collective responsibility" and reasoned that this may be due to a "CONFLICT BETWEEN the COLLECTIVERESPONSIBILITY DOCTRINE AND ACTUAL MG [Military Government] POLICY [sic]," 00 alluding to the fact that many former Nazis were employed in city administrations. Such a case had been exposed by Padover, Gittler and Sweet in a damning report on Aachen (February 1945) they sent to OSS, rather than going to through the proper channels, and which Padover is said to have leaked to the press. ${ }^{61}$ Apart from the discrepancy between Allied policy and Military Government in practice, there was another conflict that got in the way of "inculcating a sense of responsibility," which has to do with the very nature and practice of Allied psychological warfare, specifically, its foundations in advertising principles and the "wedge-driving" technique.

Germans vs. Nazis: Origins and Impact of Psychological Warfare Operations in

\section{Germany}

In 1950, as the Korean War unfolded, William Harlan Hale, a former intelligence officer, first in New York and London, later as chief of Radio Luxembourg, was tasked with collecting evaluations and 
suggestions for improvements from fellow former intelligence staff. He summarises the reflections of Wallace Carroll, OWI, who had been in charge of European psychological warfare policies at the time, as follows:

In World War II, the "unconditional surrender” formula made it difficult for P.W. [psychological warfare] to win over enemy individuals until their situation became desperate; still, ways were found even within that formula to disarm the psychological resistance of many an individual before his state was desperate. This, Carroll recalls, involved selecting our main propaganda targets in such a way as to avoid giving the individual enemy listener the impression of blanket hostility on our part to everything [sic] in his world. The "real enemy," in other words, had to be carefully defined and highlighted in our P.W. output in such a way that the individual enemy listener-especially down in the rank \& file—saw in it the image of someone other than himself. All P.W. "wedge-driving" depends on the application of this technique. In waging P.W. war on German armed forces, much of the attack concentrated on their most vulnerable point-the relationship between Army and Party. ${ }^{62}$

Carroll's evaluation is striking. Within the narrow constraints of the unconditional surrender formula, the exploitation of existing grievances, weaknesses and strained relations was undoubtedly effective. Yet the technique has uncertain implications for the period of occupation, specifically, for Allied re-education efforts.

Recent scholarship has explored the impact of Allied occupation policies and practices in the post-war period. As Donald Bloxham demonstrates, “Allied 're-education' policies, by some of its techniques and messages, contributed to its own failure to inculcate a German 'memory' and sense of responsibility for the crimes of Nazism." ${ }^{3}$ He cites a lack of clarity on the question of guilt, the fact that re-education policy enabled representations of the past, in which "ordinary" Germans were absolved of guilt and responsibility or appeared as victims, accommodating and fortifying Germany's particular strategy of "mastering the past." ${ }^{4}$ Similarly, William Mikkel Dack argues that the shared experience of completing a denazification questionnaire, of which around 20 million were distributed in the four occupation zones (primarily in the US zone), i.e. reaching around a third of the German population, had a significant, perhaps lasting effect on Germans and their "construction of early postwar personal narratives." 65 
As a corrective to the focus on the immediate post-war period, I argue that the lasting effect of Allied policies so convincingly demonstrated by Bloxham and Dack also applies in the case of psychological warfare outputs prior to the end of the war in Europe. Dack claims that the impact of the questionnaire may be bigger than that of "denazification radio broadcasts, mandatory film screenings, or a tour of a concentration camp." ${ }^{6}$ Left to be explored is the interplay between denazification self-evaluations and the Nuremberg Trial, press coverage, other denazification measures, etc., which can be presumed to have affected the direction, tone, even vocabulary of supporting information supplied by Germans seeking to be permitted to continue their current employment or take up a new position. The assertion that "The Fragebogen acted as a blank canvas upon which Germans documented their personal history of living under the Third Reich and constructed narratives about their relationship with the Nazi regime, narratives often clothed in strong emotions," can thus be qualified and the Fragebogen be embedded in the wider, complex context of the early postwar years, and indeed the final months of the war, which were, as we have seen, all but a clean slate. ${ }^{67}$

As troops, which were supported by CIC officers, entered newly conquered towns and cities, black lists and automatic arrest category instructions enabled them to remove from office, intern and arrest. Dack notes how the arrests were a cause of anxiety among the local populations who were not privy to the criteria leading to internment. ${ }^{68}$ So even before the specifics of denazification were known, already from autumn 1944 onwards, Germans had to consider the extent of their own involvement, how it would affect them, and how they would represent it to the occupying forces. ${ }^{69}$

As mentioned above, PWD's field interrogations and other forms of intelligence gathering informed the production of leaflets and radio broadcasts. In the following, I will draw attention to what may be wider ramifications of psychological warfare operations for later German self-representations. Specifically, the way in which Germans on any part of a spectrum of complicity tend to separate between themselves and the "real Nazis" in many contemporary sources and post-war accounts, was possibly reinforced and lent legitimacy by psychological warfare propaganda—already before the end of hostilities.

To a degree, psychological warfare output ran counter to psychological warfare's own standing directive, namely, that "The use of Psychological Warfare in military operations must however be strictly subordinated to the long-term policy of our Governments. In the sense that nothing must be done to 
undermine fighting morale during operations which would prejudice Government policy to Germany after the war." ${ }^{\prime 0}$ One of the psychological warfare leaflets, for instance, purports to answer questions posed by German soldiers captured in Italy, including the following:

"Will we be held responsible for the acts of our Nazi leaders and of the Waffen-SS?"

Their officers had told them that, if they were captured, the Americans and English would mistreat them. They feared a mass vengeance for the deeds committed in Germany's name in occupied Europe.

They should have known that the Anglo-Saxons always treat their prisoners "fair"—with chivalry and decency. No German soldier is ever held responsible for the deeds of his leaders. German prisoners of war get the same food and care as English and American soldiers. And after the war they will be able to return home to their families and help to build up a new and better Germany. ${ }^{71}$

The "wedge-driving technique" is arguably ill-suited for holding to account post-conflict a society complicit to different degrees in systematic exclusion, expropriation, expulsion and extermination. In the above example, it helped reinforce notions of an unpolitical Wehrmacht and foster a sense of impunity. Intelligence officers' frequently voiced expectations of admissions of guilt and responsibility from Germans are thus at odds with the most fundamental psychological warfare techniques they employed and supported. The extent to which these techniques had an impact on Germans and the outcome of the war is difficult to establish. But there can be no doubt that the radio programmes and leaflet campaigns reached a significant number of German civilians and soldiers. ${ }^{72}$

A representative questionnaire study administered in June 1945 among 666 adults aged 18 to 55 in Marburg, Hersfeld and Eschwege sought to "obtain a quantitative measure of the extent to which Allied radio programmes were listened, of German attitudes towards them and of the effect which they produced." 73 According to the survey results, 51 percent of the population had listened to Allied radio broadcasts, though listening numbers varied according to gender, occupation and political outlook. Radio Luxembourg was the "most popular of Allied stations," followed by the BBC. ${ }^{74}$ Just under half of those who professed to listening to Allied radio broadcasts had listened to the Supreme Commander's proclamations, with many passing on the information to others. ${ }^{75}$ 
The survey also evaluated civilians' exposure to leaflets during the war, of which billions were dropped. ${ }^{76}$ An average of 30 percent professed to having seen leaflets, with men, Catholics and the more highly educated significantly more likely to have been exposed to them. Similar to radio listeners, just under half passed the leaflets on to others. Radio broadcasts were considered more accurate than leaflets. The more memorable leaflet contents included statements alluding to the consequences of the "wedge-driving" technique: Survey respondents cited leaflets that highlighted "The poor leadership of the German Government;" "Details about the useless efforts and waste of men's lives by the leading Generals of the Wehrmacht;" or "That the Allies intend to abolish only the Nazi regime and appeal to the German people for support."'77 A survey by Major Martin F. Herz, who was Chief Leaflet Writer for PWD, after having been in charge of leaflet writing and POW interrogation for the combat propaganda team of the Fifth Army in Italy, reported that two leaflets, in particular, proved highly successful: SHAEF's Safe-Conduct letter and One minute which may save your life, the latter of which "salved the feelings of the enemy by crediting him, by implication, with great soldierly virtue; it accommodated his alibi of material inferiority; it described him in soldierly (non-political) terms, avoiding any political arguments; it did not overly praise captivity; and it 'left the decision to the reader,' seemingly not urging him to desert."'78

Crucially, such leaflets did not originate in a vacuum, but were carefully crafted and primed, and, in part, based on and tested in interrogations, which allowed confirming their effectiveness and further refinement. The degree of effectiveness was further probed by the number of leaflets that were found on captured German soldiers; recollections of leaflets among POWs and their discussion; description of their surrender; German counter-propaganda reacting to Allied leaflets; and comments by the Wehrmacht command, which they gleaned from captured documents. A few years after the war, Herz countered the perception and charge of the failures of wartime propaganda on the grounds that "Re-education is not a task of psychological warfare, but of postwar reconstruction" 79 and defended the psychological warfare techniques of "wedge-driving" and finding "common ground." ${ }^{0}$ With regards to civilians, Herz elaborated his conviction that "most propaganda directed to enemy civilians will have little concrete effect on the course of a war. In fact ... little can be gained from propaganda directed toward enemy civilians in wartime, except by way of building up credibility. Thus our enormous leaflet output which was dropped 
on Germany during the war ... can really be judged only in terms of whether it built up belief in our essential honesty." $\$ 1$

The potential impact of psychological warfare techniques on civilians, and of seeking to build up "credibility" in this particular way, is indicated in the interrogation of seventy German civilians, a cross section of the population in the Western zones (Cologne, Kassel, Erfurt, Koblenz, Kaiserslautern, Marburg, Heidelberg, and a number of villages), in early June 1945 about their reactions to atrocities. In this evaluation, Janowitz, who was then serving as intelligence officer and analyst for PWB, established that Germans would either claim ignorance of the conditions inside the camps, or the impossibility of agency under Nazism. Such claims were found among "All types of personalities and social classes ... In order to buttress their argument, a few sophisticated civilians pointed to the past programs of B.B.C. and Radio Luxembourg, which had attacked the Nazi leaders as the 'real war criminals."'82 Anti-Nazis would criticize them for separating between party and non-party members as "running counter to attempts to develop a sense of collective responsibility among the German people. Military government policy was leading many Germans who had traveled complacently on the Nazi bandwagon to consider that they would not have to bear any responsibility, since only Nazi party members were being punished." 83 This alerts us to the fact that Allied attitudes, policies, and practices were rather confused in this period, including on the British side, as recent scholarship on the PWE and strategic bombing has demonstrated. The question of whether to target all Germans or only "Nazis"-however defined-proved to be a contentious issue. ${ }^{84}$

Janowitz was not alone in recording such sentiments. Parloff, too, commented on this issue. Reflecting on the conduct of the occupying troops and "the policy of 'We Come as Conquerors, not Liberators'," he wrote to his wife in January 1945: "The Germans here had gained the erroneous impression that the Americans were coming to liberate Germany from the Nazi Yoke. They claim our radio propaganda told them so. I don't know if that's true or not." ${ }^{55}$ Especially "anti-Nazis" would challenge the Allied occupation forces after the end of the war, as noted in an intelligence report from July 1945, according to which they would complain that "We (anti-Nazis) and you (Americans) used to maintain that this war was waged against Nazism and not against the German people." ${ }^{86}$ Contrary to Herz's assertions, the credibility 
built during the war through propaganda was thus seemingly undermined in some quarters in the immediate post-war period.

Given what may be modest gains of psychological warfare among the civilian population during wartime, with its aims focussed on achieving long-term post-war goals, this strategy may have obstructed reeducation aims. They largely fed Germans what they wanted to hear to build up credibility, only to then contradict their previous messaging as soon as the war was over. Indeed, McGranahan, perhaps still unsettled by his encounter with the child survivors of Buchenwald, appeared to have felt uneasy about the strategy, musing not long after the war:

We did, of course, attempt in some degree to destroy the central core of German loyalty, but we could have attempted much more. We could have told the Germans quite honestly what we thought about Hitler; we could have given the same attention before the collapse as we did afterward to the aggression, sadism, and brutality of the Nazi regime, its loathsomeness to the civilized world, and the role of the German people in tolerating it; we could have concentrated much more than we did on encouraging and organizing the anti-Nazis, remembering that if 60 percent professed loyalty to Hitler, 40 percent did not. There is no way of knowing today what the consequences would have been if we had followed such a policy. It is difficult enough to evaluate the effects of propaganda we did employ, let alone policies we never put into operation..$^{87}$

For McGranahan, the problem lies in the fact that in the US, propaganda is based on advertising and public relations principles, in which it is paramount not to offend, but to find a common denominator. In a psychological warfare context, "established values and symbols" are not attacked. Instead, the focus is on less ideological issues. ${ }^{88} \mathrm{He}$ voices his "personal opinion that our policy was wrong in shrinking from ideological attack and modelling itself on advertising methods. ... With the occupation, we radically changed from the advertising to the evangelical type of propaganda. Now we are full of moral indignation, we sternly condemn the common man in Germany for sinfully participating in the Nazi cause, and we openly avow our purpose of converting the Germans to democracy. The Germans, of course, are quite surprised at this change. Bolder ones among them complain that if we thought it was 
futile to try to encourage them to turn against the Nazi leadership during the war, we are being somewhat inconsistent now in blaming them for having failed to do so." ${ }^{99}$

Richard Crossman, former head of PWE's German Section and later assistant chief of PWD, and a Labour MP from 1945, admitted in an address to the Royal United Services Institution in 1953 that Parliament, had it been able to openly discuss the propaganda directed at Germans, "would have complained that the propaganda organization was 'appeasing' the Germans. But it was essential to make leaflets objective and credible to a German [sic]-not to the House of Commons!"'90 Similar to Herz, Crossman continued to defend the strategy by maintaining that "it is not only necessary to say the truth; it must be the credible [sic] truth. You have to eliminate a great many things which are true if the enemy will not believe them to be true." ${ }^{91}$ In other words, to build and maintain Allied credibility with Germans, less "credible" —or less palatable—elements of the truth were omitted, with unknown but potentially farreaching consequences.

\section{Conclusion}

The final seven months of the war prove significant for our understanding of evolving Allied attitudes towards Germans, and German responses towards the occupation forces and their own involvement in the "Third Reich." Intelligence officers were among the first of the Allies to interact with German civilians and to question them about their attitudes and behaviors. Among the Allies, there was considerable uncertainty and ambiguity what to expect when entering Germany. The intelligence officers' approaches to psychological profiling, professional and personal backgrounds, along with ideas about national character and collective guilt, shaped their encounters and German civilians' responses.

The analysis of intelligence officers' interrogations and reports adds to the discourse surrounding Allied notions of complicity, guilt and responsibility in the latter months of the war. In the long history of seeking to separate between "active" and "nominal" Nazis, "Nazis" and "anti-Nazis", "good bets" and "bad bets", "Germans" and "Nazis", or, more recently, "perpetrators" and "bystanders", the Western Allies' definition of guilt and responsibility was initially very wide, if ill-defined. It increasingly narrowed after war's end in the context of Cold War practicalities, denazification and war crimes trials, but has more recently expanded again to include forms of everyday complicity. Psychological warfare research and operations have received scant attention in this development. But as this article has demonstrated, the 
reports and profiles offer an intimate view at early encounters between Allies and German civilians, and their disparate notions of culpability. The interrogations of civilians, and intelligence officers' often astute, if at times polemical, analyses, which, together with POW interrogations and observations, informed the more widely researched radio broadcasts and leaflet campaigns, thus deserve a closer look than previously afforded.

Psychological warfare operations directed at civilians were intended to build up credibility for the period of occupation, after the hostilities had ended. It was assumed in intelligence circles that Germans would only accept certain aspects of the truth. Any contentious issues were therefore omitted, a psychological warfare practice, which has its roots in the application of advertising and marketing principles. It is closely connected to another key technique, the exploitation of existing grievances and weaknesses, e.g. between soldiers and army leadership, or between the people and government. In this manner, a firm line was drawn between Germans and Nazis. Psychological warfare operations did not develop in a vacuum. Leaflets and radio broadcasts were developed through POW interrogations, clandestine recordings, and surveys, along with civilian interrogations; and in turn, the effectiveness of said output was tested on these groups.

Taking place before any details of post-war denazification and criminal prosecutions were known, before exculpation and defence strategies were publicised and hardened, the PWD reports and profiles attest to civilians who until April/May 1945 readily admitted to having known about atrocities, yet who already distanced themselves from any role in the process, and indeed from "the Nazis". Psychological warfare operations are not responsible for these claims, yet may well have played a part in reinforcing them. Not least as strategies or performances towards the intelligence officers, using tropes and slogans Germans knew originated or would resonate with the Allies, who, in turn, had concluded from their POW surveys and interrogations that this was going to be the most successful psychological warfare strategy. It ran counter to many intelligence officers' own observations, attitudes, and analyses, as expressed in reports and correspondence both at the time and after the war. It further undermined the objective of instilling a sense of guilt and/or responsibility in Germans, whether personal or collective, and may have ultimately weakened Allied credibility. 
For their invaluable comments and suggestions on an earlier version of this article, I am grateful to Tobias Becker, Mary Fulbrook, Stephanie Bird, and the anonymous reviewers.

${ }^{1}$ Richard Overy, Interrogations: The Nazi Elite in Allied Hands, 1945 (London: Allen Lane The Penguin Press, 2001). Sönke Neitzel and Harald Welzer, Soldaten: Protokolle vom Kämpfen, Töten und Sterben (Frankfurt am Main: S. Fischer, 2011); Felix Römer, Kameraden: Die Webrmacht von Innen (Munich: Piper, 2012). A notable exception to the overall focus on soldiers and organizations is Perry Biddiscombe's study of intelligence reports on the "Edelweißpiraten": “'The Enemy of Our Enemy': A View of the Edelweiss Piraten from the British and American Archives," Journal of Contemporary History 30, No. 1 (1995): 37-63. For an evaluation of surveys of Allied Wehrmacht morale undertaken by former PWD, SHAEF staff, see Muriel I. Gurfein and Morris Janowitz, "Trends in Wehrmacht Morale," The Public Opinion Quarterly 10, no. 1 (Spring, 1946): 78-84; Edward A. Shils and Morris Janowitz, "Cohesion and Disintegration in the Wehrmacht in World War II," The Public Opinion Quarterly 12, no. 2 (Summer, 1948): $280-315$.

${ }^{2}$ See e.g. Katrin Schreiter's gender analysis of the transcripts resulting from US Strategic Bombing Survey interviews with Germans in Darmstadt from April and May 1945: "Revisiting Morale under the Bombs: The Gender of Affect in Darmstadt, 1942-1945," Central European History 50, no. 3 (2017): 347-374; Mark Clodfelter, "Aiming to Break Will: America's World War II Bombing of German Morale and its Ramifications," The Journal of Strategic Studies 33, no. 3 (2010): 401-435; Richard Overy, "Making and Breaking Morale: British Political Warfare and Bomber Command in the Second World War," Twentieth Century British History 26, no. 3 (2015): 370-399; Thomas Childers, 'Facilis descensus averni est': The Allied bombing of Germany and the Issue of German Suffering," Central European History 38, no. 1 (2005): 75-105.

3 See e.g. Sean Longden, T-Force: The Race for Nazi War Secrets, 1945 (London: Constable, 2009); Stephen G. Fritz, Endkampf: Soldiers, Civilians, and the Death of the Third Reich (Lexington, KY: The University Press of Kentucky, 2004); Richard Breitman, Norman J.W. Goda, Timothy Naftali and Robert Wolfe, U.S. Intelligence and the Naris (Cambridge: CUP, 2005); Perry Biddiscombe, The denarification of Germany: a history 1945-1990 (Stroud: Tempus, 2007); KlausDietmar Henke, Die amerikanische Besetzung Deutschlands (3 ${ }^{\text {rd }}$ edition, Munich: Oldenbourg, 2009). For example, Lieutenant-Colonel Murray I. Gurfein, Chief of Intelligence, PWD, SHAEF, was among the interrogators of the Staff Section of the Interrogations Division at Nuremberg. Overy, Interrogations, 77. The Psychological Warfare Division (PWD) became the Information Control Division (ICD) after the end of the war. Erwin J. Warkentin (ed.), History of the Information Control Division: OMGUS, 1944 to June 30, 1946, 
http://www.erwinslist.com/Files/History\%20I.pdf (Accessed December 13, 2018), 3. For an overview of the development of psychological warfare since the First World War, see Philip M. Taylor, "From Psychological Warfare to Information Operations and Back Again," ed. George Kassimeris and John Buckley, The Ashgate Research Companion to Modern Warfare (London: Routledge, 2010), 419-432.

${ }^{4}$ Sara Ahmed, Strange Encounters: Embodied Others in Post-Coloniality (London: Routledge, 2000), 6.

${ }^{5}$ Sara Matthews, “The trophies of their wars': affect and encounter at the Canadian War Museum," Museum Management and Curatorship 28, no. 3 (2013): 273.

${ }^{6}$ See e.g. Peter Longerich, "Davon haben wir nichts gewnsstt." Die Deutschen und die Judenverfolgung 1933-1945 (Munich: Siedler, 2006); Bernward Dörner, Die Deutschen und der Holocaust: Was niemand wissen wollte, aber jeder wissen konnte (Berlin: Propyläen, 2007); David Bankier, Die öffentliche Meinung im Hitler-Staat. Die 'Endlösung' und die Deutschen: Eine Bericbtigung (Berlin: Arno Spitz, 1995); Otto D. Kulka and Eberhard Jäckel (eds.), Die Juden in den geheimen NSStimmungsberichten 1933-1945 (Düsseldorf: Droste, 2004); Eric A. Johnson and Karl-Heinz Reuband, What We Knew: Terror, Mass Murder, and Everyday Life in Nazi Germany: An Oral History (Cambridge, MA: Basic Books, 2005).

7 Thomas Boghardt, “America’s Secret Vanguard: US Army Intelligence Operations in Germany, 1944-47,” Studies in Intelligence 57, no. 2 (June, 2013): 1-3. In the American context, the OSS was chiefly responsible for intelligence gathering, CIC was entrusted with and countering enemy espionage and sabotage and intelligence gathering, and G$2 s$ at division, army and theatre level engaged in interrogation, interpretation, photo interpretation, and order of battle.

${ }^{8}$ Hemant Shaw, The Production of Modernization: Daniel Lermer, Mass Media, and the Passing of Traditional Society (Philadelphia: Temple University Press, 2011), 32-33; 47; Warkentin, History of the Information Control Division, 156. Following SHAEF's dissolution on 13 July 1945, the work of the Intelligence Section of PWD was assumed by the Intelligence Branch of the Information Control Division USFET. In addition, in October 1945 a Surveys Unit was created, and the Branch was allocated to Information Control Division (ICD) in February 1946, responsible for political intelligence reporting for Military Government.

${ }^{9}$ Shaw, The Production of Modernization, 38-39.

10 The OSS Research \& Analysis's Central European Section played an important role in denazification planning, employed many German-Jewish scholars who had fled Germany, and included some of the scholars of the Frankfurt School. William Mikkel Dack, Questioning the Past: The Fragebogen and Everyday Denarification in Occupied Germany (Unpublished thesis, University of Calgary, 2016), 86; see also Franz Neumann, Herbert Marcuse and Otto Kirchheimer, Secret Reports on Nazi Germany: The Frankfurt School Contribution to the War Effort, ed. by Raffaele Laudan, 
with a foreword by Raymond Geuss (Princeton University Press, 2013); Guy Stern, "In the Service of American Intelligence: German-Jewish Exiles in the War Against Hitler,” The Leo Baeck Institute Year Book 37, no. 1 (1 January 1992): 470.

${ }^{11}$ New York Public Library, Manuscripts and Archives Division (NYPL), Saul K. Padover Papers, MssCol 2325, Special Reports 1944, Alfred Toombs, “Aachen Report. To: Messrs. Sweet, Padover, and Gittler, Ninth Army,” February 14, 1945. Prior to interrogating German civilians, they had interviewed civilians in France, Luxembourg and Belgium.

12 These were "used and circulated by G-2 and G-5 Army and Army Group levels, by Psychological Warfare Division of SHAEF and by civilian agencies concerned with German policy. Over a period of months, Dr. Padover's reports came to be regarded as the most accurate and interesting political intelligence material to come out of Germany. The reports have been sought after in the highest Hqs." National Archives at College Park, MD (NACP), RG226, Entry 224, Box 580, OSS Personnel Files, Padover, Saul K., Alfred Toombs to Commanding Officer, P\&PWDet., 12 AG, APO 655, Recommendation for Bronze Star, May 24, 1945. See also commendation of Dr Paul Sweet for the award of a Bronze Star, praising his reports and analyses, and their use in policymaking. NACP, RG226, Entry 224, Box 761, OSS Personnel Files, Sweet, Dr. Paul R., Alfred Toombs to Commanding Officer, P\&PWDet., 12 AG, APO 655, Recommendation for Bronze Star, May 24, 1945.

${ }^{13}$ For more on Lasswell, see e.g. Lynette Finch, "Psychological Propaganda: The War of Ideas on Ideas During the First Half of the Twentieth Century," Armed Forces \& Society 26, no. 3 (April, 2000): 367-386; Nick Dorzweiler, "Frankfurt Meets Chicago: Collaborations between the Institute for Social Research and Harold Lasswell, 19331941," Polity 47, no. 3 (July, 2015): 352-375.

${ }^{14}$ See a round-table discussion including Gittler's daughter, Wendy Gittler, following the film's screening at New York University in 2012: http://www.casaitaliananyu.org/node/6176 [Accessed January 1, 2019].

${ }^{15}$ Paul R. Sweet, "Interview with Paul Sweet," The Historian 59, no. 2 (December, 1997): 284.

${ }^{16}$ NYPL, Saul K. Padover Papers, MssCol 2325, Photos Articles Notes Clippings, Saul Padover and Lewis Gittler, "Edelweiss Pirates: German Youth in Revolt?," nd; NYPL, Saul K. Padover Papers, MssCol 2325, Profiles 1944-45, Saul Padover and Lewis Gittler, “A Nazi real estate broker," November 19, 1944; -- "A middle-aged Social Democrat, a little man who never compromised," December 12, 1944; -- "Anti-Nazi daughter of a Nazi," December 9, 1944; -- “Unpolitical' German Girl," October 26, 1944; -- "Father and Wife of an SS-Man," November 9, 1944; -- “A race-conscious and Nazified girl,” January 23, 1945. 
${ }^{17}$ For reports and profiles mentioning atrocities against Jews and Russians, see e.g. NYPL, Saul K. Padover Papers, MssCol 2325, Profiles 1944-45, Saul Padover and Lewis Gittler, "The Burgermeister of a small German town," October 18, 1944; Saul Padover, "Young German Stenographer," October 18, 1944; -- Saul Padover and Lewis Gittler, “Unpolitical' German Girl,” October 26, 1944; -- Saul Padover and Lewis Gittler, “An engineer from Cologne,” October 29, 1944; -- Saul Padover and Lewis Gittler, “An 'anti-Nazi’ school teacher digs trenches \& likes it,” March 16, 1945; -- Saul Padover and Lewis Gittler, “A Hitler Youth: 14,” March 25, 1945; -- Saul Padover and Lewis Gittler, "German university students - preliminary report,” March 30, 1945; NYPL, Saul K. Padover Papers, MssCol 2325, Special Reports 1944, Saul Padover and Lewis Gittler, "An impression of Germans in Germany," December 3, 1944.

${ }^{18}$ Daniel Lerner, Sykewar: Psychological Warfare Against Germany, D-Day to VE-Day (New York: George W. Stewart, 1949), 128. Lerner served with PWD in Paris from September 1944 until May 1945 and was Chief of Intelligence of the Information Control Division, OMGUS from 1945 to 1946. After the war, Lerner's doctoral thesis focused on PWD and he subsequently became a professor of sociology, concentrating specifically on mass media. See Shaw, The Production of Modernization, 31; Earl F. Ziemke, The U.S. Army in the Occupation of Germany 1944-1946 (Washington, D.C.: Center of Military History United States Army, 1990).

${ }^{19}$ See in this context e.g. Bastiaan Willems, "Nachbeben des Totalen Kriegs: Der Rückzug der Wehrmacht durch Ostpreußen und seine Folgen," Vierteljahrshefte für Zeitgeschichte 66, no. 3 (2018): 403-434.

20 See e.g. Richard Overy, The Bombing War: Europe, 1939-1945 (London: Allen Lane, 2013); Overy, "Making and Breaking Morale: British Political Warfare and Bomber Command in the Second World War"; Mark Clodfelter, “Aiming to Break Will: America's World War II Bombing of German Morale and its Ramifications," The Journal of Strategic Studies 33, no. 3 (2010): 401-435; Mark Connelly, "The British People, the Press and the Strategic Air Campaign against Germany, 1939-45," Contemporary British History 16, no. 2 (2002): 39-48; Alex J. Bellamy, "The Ethics of Terror Bombing: Beyond Supreme Emergency," Journal of Military Ethics 7, no. 1 (2008): 41-65; Alan J. Levine, The strategic bombing of Germany, 1940-1945 (New York: Praeger, 1992).

${ }^{21}$ Emory University, Emory Center for Digital Scholarship, Washington D.C., Witness to the Holocaust, Morris P. Parloff Interview, interviewed by Lily $\quad$ Singer, $\quad$ May $10, \quad 1980$, https://witness.digitalscholarship.emory.edu/items/show/76 [Accessed 14 September 2018]. After the war, Parloff spent 30 years as administrator and researcher at the National Institute of Mental Health, taught at different universities, conducted research on personality characteristics, and maintained a psychotherapy practice. On the socalled "Ritchie Boys," US Army intelligence personnel, many of whom were German Jews, see e.g. Stern, "In the 
Service of American Intelligence;" Bruce Henderson, Ritchie Boys: The Jews who escaped the Naris and returned to fight Hitler (William Collins, 2018); Boghardt, “America’s Secret Vanguard;” Kevin M. Aughinbaugh "The Castle of Intelligence: Camp Ritchie Maryland and the Military Intelligence Training Center during the Second World War," The Gettysburg Historical Journal 17, Article 5 (2018), https://cupola.gettysburg.edu/ghj/vol17/iss1/5; Christian Bauer and Rebekka Göpfert, Die Ritchie Boys: Deutsche Emigranten beim US-Geheimdienst (Makrobooks, 2016); Longden, TForce: The Race for Naz̨i War Secrets, 1945; Berrin A. Beasley, "Hier 1st 1212: Operation Annie, World War II Allied Psychological Warfare, and the Capture of the Rhineland," Journal of Radio Studies 8, no. 1 (2001): 104-121.

${ }^{22}$ United States Holocaust Memorial Museum Archives, Washington, D.C. (USHMM), Morris B. Parloff papers, 2015.495.1, Folder 5: Correspondence: compilation, typescript, titled "World War Two Lite: Highlights of Letters. From Morris to Gloria Parloff, 1942-1945." Typescript, 2001, Morris B. Parloff, Letter from Morris B. Parloff to Gloria Parloff, November 2, 1944.

${ }^{23}$ Ibid., Morris B. Parloff, Letter from Morris B. Parloff to Gloria Parloff, , January 23, 1945; -- 20 April 20, 1945.

${ }^{24}$ NACP, RG338, Entry P50385, Box 1, 15th Army G-2 Periodic Rep Apr-Jul 1945, Annex No. 2 to Fifteenth U.S. Army. G-2 Periodic Report No. 14, April 14, 1945. See also Johannes Kleinschmidt, “Do not fraternize”: Die schwierigen Anfänge deutsch-amerikanischer Freundschaft 1944-1949 (Trier: Wissenschaftlicher Verlag Trier, 1997).

25 In all intelligence reports, country names are usually spelt in capital letters.

${ }^{26}$ NACP, RG338, Entry P50385, Box 1, 15th Army G-2 Periodic Rep Apr-Jul 1945, Annex No. 3 to Fifteenth U.S. Army. G-2 periodic Report No. 18, April 19, 1945.

${ }^{27}$ On the Werewolves, see e.g. Perry Biddiscombe, Werwolf! The History of the National Socialist Guerrilla Movement, 1944-1945 (Toronto: University of Toronto Press, 1998); Christina von Hodenberg, “Of German Fräuleins, Nazi Werwolves, and Iraqi Insurgents: The American Fascination with Hitler's Last Foray," Central European History 41 (2008): 71-92.

${ }^{28}$ NACP, RG338, Entry P50385, Box 1, 15th Army G-2 Periodic Rep Apr-Jul 1945, Annex No. 4 to Fifteenth U.S. Army. G-2 periodic Report No. 26, April 27, 1945.

${ }^{29}$ Lerner, Sykewar, 115-123. See also Shaw, The Production of Modernization, 35-38.

${ }^{30}$ Martin Roiser and Carla Willig, "The strange death of the authoritarian personality: 50 years of psychological and political debate," History of the Human Sciences 15, no. 4 (2002): 71-96.

31 Yale MSSA, William Harlan Hale Papers, MS 1140, Series IV: Topical Files: Box 18, Folder 22, Directives Allied. Annex E: Principles and Procedures in Selecting Direct Licensees and Employees, SHAEF, PWD, Directive No. 2 for Information and Control Services, May 28, 1945. 
32 Dack, Questioning the Past, 66.

33 Ibid., 167.

34 Yale MSSA, William Harlan Hale Papers, MS 1140, Series IV: Topical Files: Box 18, Folder 22, Directives Allied. Annex E: Principles and Procedures in Selecting Direct Licensees and Employees, SHAEF, PWD, Directive No. 2 for Information and Control Services, May 28, 1945.

35 Kleinschmidt, “Do not fraternize," 29-30.

${ }^{36}$ Saul K. Padover, Lügendetektor: Vernehmungen im besiegten Deutschland 1944/45 [1946] (Berlin: Die andere Bibliothek, 1999), 292-296.

${ }^{37}$ NYPL, Saul K. Padover Papers, MssCol 2325, Special Reports 1944, Saul Padover, “An impression of Germans in Germany," 12 AG, December 3, 1944; ibid., Saul Padover, "Reflections on the 'hard policy' towards Germany," December 26, 1944.

38 Padover, Lügendetektor, 334.

${ }^{39}$ Saul Padover, Experiment in Germany: The Story of an American Intelligence Officer (New York: Duell, Sloan and Pearce, 1946). His book was translated into German as late as 1999 and published under the title Lügendetektor: Vernebmungen im besiegten Deutschland 1944/45 ("Lie detector: Interrogations in vanquished Germany 1944/45”), and recently dramatized by German broadcaster ZDF (Die Suche nach Hitler's Volk, dir. Alexander Berkel and Peter Hartel, 2015). ${ }^{40}$ NYPL, Saul K. Padover Papers, MssCol 2325, Notebooks 1944-1945, nd. [May or June 1945].

${ }^{41}$ See e.g. NYPL, Saul K. Padover Papers, MssCol 2325, Profiles 1944-45, Saul K. Padover and Lewis F. Gittler, “A Socialist who did Nazi occupation work in Russia," February 21, 1945; Saul K. Padover and Lewis F. Gittler, "A middle-aged Social Democrat, a little man who never compromised,” December 12, 1944.

${ }^{42}$ For the contemporary discourse on collective guilt, see Lord Robert Vansittart, Black Record: Germans Past and Present (London: Hamish Hamilton 1941); -- Roots of the Trouble (London and Melbourne: Hutchinson \& Co, 1942); -Germany From Defeat To Conquest 1913-1933 (Edinburgh: Hugh Paton and Sons, Ltd., 1945); Carl G. Jung, "After the Catastrophe," in Essays on Contemporary Events: The Psychology of Nazism, trans. R.F.C. Hull (Princeton: Princeton University Press, 1989); Karl Jaspers, The Question of German Guilt (New York NY: Capricorn Books, 1961)/Die Schuldfrage (Heidelberg: Lambert Schneider, 1946); Hannah Arendt, “Collective Responsibility,” ed. James Bernauer, Amor Mundi: Explorations in the Faith and Thought of Hannah Arendt (Dordrecht: Martinus Nijhoff, 1987); Hannah Arendt, "Personal responsibility under dictatorship," The Listener (6 August 1964): 185-7, 205; Hannah Arendt, "The aftermath of Nazi rule: report from Germany," Commentary (October 1950): 342-53. For an overview, see Jeffrey K. 
Olick, In the House of the Hangman: The Agonies of German Defeat, 1943-1949 (Chicago and London: Chicago University Press, 2005); -- “The Guilt of Nations?,” Ethics \& International Affairs 17, no. 2 (2003): 109-117.

${ }^{43}$ Ute Gerhard, Soz̧iologie der Stunde Null (Frankfurt/Main: Suhrkamp, 2005), 84; Directive to Commander-in-Chief of United States Forces of Occupation Regarding the Military Government of Germany; April 1945 (JCS 1067). Taken from Yale Law School, Lilian Goldman Law Library, The Avalon Project: Documents in Law, History and Diplomacy, http://avalon.law.yale.edu/wwii/ger02.asp [Accessed December 12, 2018].

${ }_{44}$ Norbert Frei, Vergangenheitspolitik: Die Anfänge der Bundesrepublik und die NS-Vergangenheit (Munich: C.H. Beck, 1996).

45 University of Warwick, Modern Records Centre (MRC), Richard Crossman Papers, Mss.154/3/PW/1/109-114, John P. Dickson, “Notes on a Trip to Western Rhineland Area,” March 21-28, 1945.

46 Dack, Questioning the Past, 139; 143; Biddiscombe, The Denarification of Germany. See also section 6c on Denazification in the Directive to Commander-in-Chief of United States Forces of Occupation Regarding the Military Government of Germany; April 1945 (JCS 1067).

${ }^{47}$ Dack, Questioning the Past, 152-53.

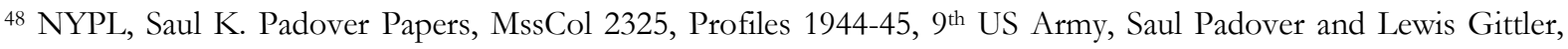
“An ex-SS man,” March 19, 1945.

49 See Bundesarchiv Berlin-Lichterfelde (BArch), R 9361/III/96585/RS C5460. The details match the information in Padover and Gittler's report. H.K., who applied for a marriage license to the SS Race and Settlement Main Office (Rasse- und Siedlungshauptamt), was born in 1923. BArch records further confirm he was a signaller in the SS, which he joined in March 1941, and prior to which he was in the Hitler Youth from November 1932 onwards.

${ }^{50}$ Tomasz Kranz, “Ewidencja Zgonowi Smiertelnosc Wiezow KL Lublin,” Zeszyty Majdanka 23 (2005): 7-53.

51 Yale MSSA, William Harlan Hale Papers, MS 1140, Series IV: Topical Files: Box 18, Folder 17, Interrogations: summary reports on attitudes, SHAEF PWD, Intelligence Section, Summary Report on the Attitudes of German Ps/W Towards the United States, June 19, 1945.

${ }^{52}$ Yale MSSA, William Harlan Hale Papers, Series IV: Topical Files: MS 1140, Box 19, Folder 29, Dept. of the Army. Civil Affairs Division. New York Field Office-study and reports: "Letters from Young Germans," November 10, 1948.

53 Seán Street, Crossing the Ether: Public Service Radio and Commercial Competition in Britain with special reference to Pre-War Broadcasting (PhD diss., Bournemouth University, 2003), 381. 
${ }^{54}$ NYPL, Saul K. Padover Papers, MssCol 2325, Profiles 1944-45, Correspondence Donald McGranahan to Chief, Intelligence Section, PWD/SHAEF, “The children in Buchenwald,” May 4, 1945,.

55 NYPL, Saul K. Padover Papers, MssCol 2325, Special Reports 1944, Captain Donald McGranahan, “A Talk to the Children of Buchenwald," April 24, 1945.

${ }^{56}$ WRC, Richard Crossman Papers, MSS.154/3/PW/1/67-71, Daniel Lerner, "Notes on a trip through occupied Germany," April 18, 1945.

${ }^{57}$ Morris Janowitz, “German Reactions to Nazi Atrocities,” American Journal of Sociology 52, no. 2 (Sep., 1946$): 145$.

58 Donald Bloxham, "The Genocidal Past in Western Germany and the Experience of Occupation, 1945-6," European History Quarterly 34, no. 3 (2004): 311.

${ }^{59}$ Yale MSSA, William Harlan Hale Papers, MS 1140, Series IV. Topical Files, Box 18 folder 6, Reports on morale, William Harlan Hale, “German mind”. Summary from notes on soldiers and civilians. May 1944-Jun 1945. See also Philip M. Taylor, "From Psychological Warfare to Information Operations and Back Again,” ed. George Kassimeris and John Buckley, The Ashgate Research Companion to Modern Warfare (London: Routledge, 2010): 422.

${ }^{60}$ Yale MSSA, William Harlan Hale Papers, MS 1140, Series IV. Topical Files, Box 18 folder 6: Reports on morale, William Harlan Hale, “German mind”. Summary from notes on soldiers and civilians, May 1944-Jun 1945.

${ }^{61}$ NYPL, Saul K. Padover Papers, MssCol 2325, Special Reports 1944, Alfred Toombs, Aachen Report. To: Messrs. Sweet, Padover, and Gittler, Ninth Army, February 14, 1945; ibid. Saul Padover, Lewis Gittler and Paul Sweet, "The Political Situation in Aachen," February 2, 1945. See also Henke, Die amerikanische Besetzung Deutschlands; Biddiscombe, Denazification.

${ }^{62}$ Yale MSSA, William Harlan Hale Papers, MS 1140, Series IV: Box 18, folder 26: Interview reports with psychological warfare personnel 1948, 1950, William Hale, Person Interviewed: Wallace Carroll, May 15, 1950. At that time, Carroll was newspaper editor with the Division of Public Affairs, Department of State.

${ }^{63}$ Bloxham, "The Genocidal Past in Western Germany and the Experience of Occupation, 1945-6," 306.

${ }^{64}$ Ibid., 306-307.

${ }^{65}$ Dack, Questioning the Past, 253.

${ }^{66}$ Dack, Questioning the Past, 191.

${ }^{67}$ Ibid., 285.

68 Ibid., 196. 
${ }^{69}$ Similarly, Schreiter concludes from her analysis of the US Strategic Bombing Survey interview transcript that German justifications of wartime behavior with having done only their duty already emerged in this early period in their encounter with the interviewers. Schreiter, "Revisiting Morale under the Bombs," 374.

${ }^{70}$ Yale MSSA, William Harlan Hale Papers, MS 1140, Series IV: Topical Files: Box 18, Folder 22, Standing Directive for Psychological Warfare against Members of the German Armed Forces, SHAEF, PWD, April 18, 1944.

${ }^{71}$ Yale MSSA, William Harlan Hale Papers, MS 1140, Series IV: Topical Files: Box 19, Folder 3, Leaflets, nd.

${ }^{72}$ E.g. Yale University Archives \& Manuscripts, William Harlan Hale Papers, Series IV: Topical Files, Box 18, folder 26: Interview reports with psychological warfare personnel 1948, 1950, William H. Hale, Psychological Warfare Interview Report. Person Interviewed: Wallace Carroll, May 18, 1950. For a general evaluation of "the impact of Allied propaganda on the German military and civilian population,” see Lerner, Sykewar. William R. Kintner argues that psychological warfare became effective only after the German defeat at Stalingrad. See Kintner, "The Effectiveness of Psychological Warfare," Marine Corps Gazette 32, no. 1 (January, 1947), [48-56]: 49. In the Mediterranean theatre of war, 180,000 German POWs were interviewed by questionnaire to find out about the reactions to psychological warfare. Ibid., 50. For an example of the way in which PWD field intelligence officers would suggest content for leaflets and radio broadcasts, see NYPL, Saul K. Padover Papers, MssCol 2325, Special Reports 1944, Saul Padover and Lewis Gittler, Correspondence to CO, PW Detachment, "Subject: German Civilians Shot by Wehrmacht Sharpshooters Across the Rhine at Düsseldorf. Suggested Use: Radio Luxembourg, BBC, MITTEILUNGEN, Tactical Loudspeaker, Tactical Leaflet,” March 28, 1945.

73 Yale MSSA, William Harlan Hale Papers, MS 1140, Series IV: Topical Files: Box 18, Folder 9, SHAEF-PWD, Intelligence Section, "Listening to Allied Radio Broadcasts by German Civilians under the Nazis,” June 5, 1945.

${ }^{74}$ Ibid.

${ }^{75}$ Ibid.

${ }^{76}$ Philip M. Taylor gives a figure of 1.5 billion leaflets, while Lynette Finch quotes a figure of 14 billion. See Philip M. Taylor, "Munitions of the Mind': A brief history of military psychological operations," Place Branding and Public Diplomacy 3, no. 3 (2007): 200; Lynette Finch, "Knowing the Enemy: Australian Psychological Warfare and the Business of Influencing minds in the Second World War," War \& Society 16, no. 2 (October, 1998): 71.

77 Yale MSSA, William Harlan Hale Papers, MS 1140, Series IV: Topical Files: Box 18, Folder 10, SHAEF-PWD, Intelligence Section, “Exposure during the War of German civilians to Allied Leaflets,” June 28, 1945. 
78 Martin F. Herz, "Some Psychological Lessons From Leaflet Propaganda in World War II," The Public Opinion Quarterly 13, no. 3 (Autumn, 1949): 480-481. After the war, Herz was a Foreign Service officer for 30 years and later director of Georgetown's Institute for the Study of Diplomacy.

${ }^{79}$ Ibid., 471-477.

${ }^{80}$ Ibid., 480

81 Ibid., 487-488.

82 Janowitz, “German Reactions to Nazi Atrocities," 144.

83 Ibid., 146.

${ }^{84}$ Overy, "Making and Breaking Morale: British Political Warfare and Bomber Command in the Second World War." See also Pauline Elkes, The Political Warfare Executive: a re-evaluation based upon the intelligence work of the German Section (PhD diss., University of Sheffield, 1996).

${ }^{85}$ USHMM), Morris B. Parloff papers, 2015.495.1, Folder 5: Correspondence: compilation, typescript, titled "World War Two Lite: Highlights of Letters. From Morris to Gloria Parloff, 1942-1945.” Typescript, 2001, Morris B. Parloff, Letter from Morris B. Parloff to Gloria Parloff, January 23, 1945.

${ }^{86}$ Yale MSSA, William Harlan Hale Papers, MS 1140, Series IV: Topical Files: Box 18, Folder 8, Headquarters 12th Army Group, Publicity \& Psychological Warfare, “German Attitude to American Occupation,” July 19, 1945.

${ }^{87}$ Donald V. McGranahan, "U.S. Psychological Warfare Policy," The Public Opinion Quarterly 10, no. 3 (Autumn, 1946): 448

${ }^{88}$ Ibid., 448-449. See also Richard Crossman, "Psychological Warfare," Royal United Services Institution. Journal 97, no. 587 (1952): 319-332

${ }^{99}$ McGranahan, "U.S. Psychological Warfare Policy," 449-450. See also a report that details the attitudes of "antiNazis" towards the Allied occupation, which reflects on some of these issues: Yale MSSA, William Harlan Hale Papers, MS 1140, Series IV: Topical Files: Box 18, Folder 8, Headquarters 12th Army Group, Publicity \& Psychological Warfare, Konrad Kellen, “German Attitude to American Occupation,” July 19, 1945.

${ }^{90}$ Crossman, "Psychological Warfare," 327.

${ }^{91}$ Ibid., 328. 